\title{
DANCE AND MEDIALITY: FOR AN ONTOLOGICAL AND ETHICAL DISCUSSION OF THE PERFORMATIVE BODY
}

\author{
Né Barros
}

\begin{abstract}
From the late nineteenth century we can see at least two major changes in the poetic positions in dance thus pose major challenges to philosophical and aesthetic thought about this art. The first change could be identified as a break with a legacy, a coincidental break with all the steps done by western modern dance and in particular the US. The second change could be identified with the expansion of the frontiers of dance, which includes the whole process of blurring of artistic discipline and artistic genre. The rupture and expansion are, therefore, noteworthy changes that can also be classified in post metaphysical thought. This expanded and inclusive domain of the other can still be thought through a techné not to be confused with ingenuity or the mere ability to artificer, or as an alienating eros, but as the field of performativity as permition for play and disempowerment (questioned authorship in comparison with the other), becoming therefore no man's land. In this open and undefined field, the dancing body reveals itself as the political and ethical stage par excellence (performance) and an ontological space (performativity). This is the scope of our discussion that finds in mediality the common domain of these two approaches to dance.
\end{abstract}

\section{Keywords}

Body; discourse; mediality; performativity

\begin{abstract}
Resumo
A partir dos finais do século XIX podemos assistir a pelo menos duas grandes mudanças nos posicionamentos poéticos sobre a dança, introduzindo, assim, maiores desafios ao pensamento filosófico e estético sobre esta arte. A primeira mudança poderia ser identificada como rutura com um legado, uma rutura coincidente com todos os passos dados pela dança moderna ocidental e, em particular, pela americana. A segunda mudança poderia ser identificada com a expansão das fronteiras da dança, onde se inclui todo o processo de indefinição disciplinar e de género artístico. A rutura e a expansão são mudanças assinaláveis que também podem ser enquadradas num pensamento pós-metafisico. Este domínio expandido e inclusivo do outro pode ainda ser pensado através de uma techné que não se confunde com engenho ou mera capacidade do artífice, ou ainda como eros alienante, mas também como domínio da performatividade enquanto jogo de autorização e desautorização (autoria envolvida no confronto com o outro), tornando-se, por isso, terra de ninguém. Neste campo aberto e indefinido, o corpo dançante revela-se palco político e ético por excelência (performance) e espaço ontológico abrangente (performatividade). É este o âmbito da nossa discussão que encontra na medialidade o domínio comum destas duas abordagens à dança.
\end{abstract}

\section{Palavras-chave}

Corpo; discurso; medialidade; performatividade 


\section{INTRODUCTION}

The twentieth century left no doubt about the condition of dance as an autonomous art. Western dance was exemplary in its development and proved to be a serious subject for reflections on art in general. It was not always being the case, and it is partly this transition that inspires us to develop this text. Once the dance is affirmed, it becomes a privileged domain of questioning of the Body, in particular the performative body. And what we will discuss is the performative body as the object of an ontology and an ethics of form'. For this discussion, we start from the remarkable contribution of the so-called philosopher-poets by introducing new paradigms in the reflection on the role of dance and giving it an ontological status. Next, we proceed to a questioning of dance as a device (fundamental configuration to rethink dance in the contemporaneity).

It is, therefore, from the end of the nineteenth century that one can see at least two major changes in the poetic positions in dance, posing, thus, greater challenges to philosophical and aesthetic thinking about this art. The first change could be identified as a rupture with a legacy, the rupture that the modern western dance and, in particular, the American dance produced with its principles and positionings. The second change could be identified with the expansion of the boundaries of dance, where the whole process of disciplinary or artistic genre is included. Rupture and expansion are, therefore, remarkable changes that can also be framed in a post-metaphysical thought. That is, on the one hand, we see the introduction of the body as the notion that forces us to rethink the traditional dichotomies - such as body and soul - replacing the whole transcendent apparatus with the praise of the immanent. That's where we may found the argument that supports the rupture with the paradigm of the ideal dancer. The ideal dancer is now replaced by the barefoot dancer who does not deceive the center of gravity. We know that on this earthly dancer the possibility of a transcendent interpretation is not completely deactivated, however, operatively, from the poetic point of view, the loss of interest in a body of apparently artificial appearance translates the will to return to the world and to a resident corporality in the mundane life and, thus, put the sensation on the body-heavy-weight. On the other hand, given the proliferation of new approaches to the body-in-motion, it becomes necessary to rethink the gesture in its performative and virtual comprehension that allows a displacement of terms, perspectives and dimensions, destabilizing primary identities in an irreversible way. It is in this displacement effect that we can perceive the substitution of the end by the medium and perceive the identity cell by the game of circulation between self and other, which accentuate an ethical movement in the construction of forms in general, and dance form in particular.

This expanded and inclusive domain of the other can still be thought through a techné that is not confused with ingenuity or mere craftsmanship, or even an alienating eros, but respects the domain of performativity as a game of authorization and disavowal (authorship involved in the confrontation with the other), thus becoming no man's land. Techné, as an extension of a corporality that has always been reinvented, as a theater for

' In the Da materialidade na dança (Barros, 2009) a discussion is started about the need to understand the dancing body not only in the aesthetic dimension, but also in the ethical dimension. 
the reinvention of new bodies, as performativity, seems more than ever to project itself into all performative practice, making it live in a place without frontiers and without homeland ${ }^{2}$.

In summary, we can distinguish two fundamental domains of questioning in the reconfiguration of the dancing body: that of performance (political and ethical stage par excellence) and that of performativity (enlarged ontological space). Two approaches to dance that find in the mediality their common domain of discussion.

\section{PeRformanCE: GeSTURE AS AN ETHOS EXPANSION AND OPENING}

From the abandonment of choreography in its most notational status and its discreet version to the conceptualized expanded dimension where subject and object are mixed, it is on this path that identities are problematized to infinity. The very notion of performance seems to find support in these changes and in this new paradigm. Historically linked to the plastic arts, the performance ended up being spread by other expressions and, in particular in the case of dance, contribute to the blurring of its own definition. Recall what Rose Lee Goldberg tells us about it: "the performance might be a series of intimate gestures or large-scale visual theatre, lasting from a few minutes to many hours; it might be performed only once or repeated several times, with or without a prepared script, spontaneously improvised, or rehearsed over many months" (1990, p. 8). And she proceeds by saying that

by its very nature, performance defies precise or easy definition beyond the simple declaration that it is live art by artists. Any stricter definition would immediately negate the possibility of performance itself. For it draws freely on any number of disciplines and media. (Goldberg, 1990, p. 9)

Taking into account de state of dance on our days, in extreme, we could infer an assimilation of the term dance by the one of performance which would take us very far 3 . Regardless the discussion that can be established around this formulation, what seems important is, though, to discuss what is played in the performative gesture and what makes it be performative in this extended field of performance. In the course of postmetaphysics and post-history, is it still necessary, and possible, to distinguish gesture that does not involve new categories? However, what seems clear to us is that in this expanding scope of forms the need to recover an ontological discussion not of fundamentals, but of fundamental ways of connecting the body to the world.

\footnotetext{
${ }^{2}$ Regarding this subject, in his project on the field of performativity, Filipe Martins (2016) says: "techné certainly began to be an awareness of the body itself and its instrumental potentiality. From here the body, the space where mimesis takes its origin, can only be extended; and will extend precisely through techné. The artifact is, in essence, an extension of the subject, a prosthetic extension, an extension of corporeity, whose possibilities are in principle unlimited (...). In short, techné is a cannibalism of the real and, at the same time, directs the historical project of the broad edification of the subject "(p. 308).

${ }^{3} \mathrm{~A}$ discussion that would take us far: this could be the fact that, today, it is no longer a question of understanding dance in the performance era, as some authors tend to do, but to assume performance as what is left of the mutation that the dance suffered.
} 
Historically, it has been perceived as essential the introduction of the body in the problematization of this evolution, in particular because the body makes the revisitation of the dance a reinterpretation of the world, since the body-soul relation is replaced by that body-world one. In fact, phenomenology, in its great thesis, replaces the body-soul relationship by the one of body-world, and dance will be the perfect metaphor for this way of thinking and being in life. Friedrich Nietzsche, although he has not written any text genuinely about dance, will be the author for whom dance is a metaphor of thought, while at the same time, through dance, one can understand the dynamics of the world. As Giorgio Agamben tells us: "thus spoke Zarathusta is the ballet of a humanity that has lost its own gestures" (1997, p. 18). This dance, paired with a humanity that is becoming automaton or undifferentiated, claims the thought of a body that must be recovered, where it is necessary to return. This change of plan that the body of Nietzsche's dancer promotes - the return to sensation and the abandonment of the ideal rigid form - coincides doubly with what underlies the principles of modern dance and the philosophical-poetic revolution. The body is the protagonist of an original search. The creative gesture resides in a body and it is in this act that man finds meaning. The death of God runs from this loss of meaning given exclusively by the relation to an absolute and to the transcendent.

Dance is inspiring and the best living example of this paradigm shift: dance is a real and virtual body that projects itself through being-in-gesture. In addition to dance being understood as a metaphor of thought (Nietzsche), we must think of it in its tensions with philosophy and poetry, which is why many authors have been enthusiastic about the possibility of these involvements. Rainer Maria Rilke (1875-1926) has also revealed his interest in dance and expressed a desire to write poetry for Vaslav Nijinsky (1889? 1950), the charismatic ballet dancer and choreographer of the Ballets Russes regarded as a reference for the second modernism in dance. Rilke quoted in Sorell (1994, p. 374) will have said, "I must do something to Nijinsky (...) a poetry which, so to speak, must first be absorbed and then danced" 4 . Something that is in continuity with what Rilke quoted in Sorell (1994, p. 375) will say in Dialogue: "dancers create images, but they do not explain themselves".

Dance transports this possibility of metamorphosis without the necessity of being attached to figurative narratives, and for this reason, it reveals itself a privileged area of analogy to the movement of thought itself (as a movement of becoming form). Also for this reason, dance, which until the nineteenth century was distant from the circuits of thought capable of giving it density as an autonomous art form, proves to be an object of particular interest to the so-called philosopher-poets. The discourse on dance happens to be a discourse that investigates and recovers primordial and anthropological values of dance as a representation and not only as a mode of entertainment. The texts Ballets (1886/1976) and Autre étude de danse. Les fonds dans de le Ballet. D'après une indication récente (1893/1976), de Stéphane Mallarmé, are the great testimonies of the assumption of dance as an art form and of the relevance it achieves in the field of reflection.

\footnotetext{
${ }^{4}$ Reminds us Walter Sorell of Rilke's interest in this dancer from the letter to the princess of Thum und Taxis.
} 
Indeed, dance, as an autonomous genre, is due to this more intense relationship between the multiplication and expansion of poetics and the critical eye capable of identifying its phenomenology and its complex communicative processes. Loïe Fuller, one of the examples justly quoted, is one of the first American choreographers to arrive in Europe, to whom Mallarmé will refer. We know that its importance was reflected in the new solutions of lighting that responded to the needs of the time in changing the aspect of the theater. The new valences that the light gained conquered the requirements of a renewal of the theater that did not pass exclusively through drama, but through the concrete image of the scene, through stage design, lighting and new methods of production. ${ }^{5}$

There are also other dances that are emerging and which inspire thinkers like Paul Valéry, who writes a text (Philosophie de la danse) about the theatrical street dance by the famous Argentina ${ }^{6}$. Distinguishing between Leib (the body as a lived and self-expressive corporality) of Körper (the body as object body), Valéry understands dance as a coreutic creation coinciding with the corporeal dynamics of its own creator. Valéry, with L'âme et la Danse (written during 1921), a key work of these reflections, is more concerned with the principles by which the dancer is a dancing reality in the world than with the more purely symbolic domain of the work, as happened in Mallarmér. On the one hand, it is in the alliance between poetry and philosophy that we can recognize the contribution of poets like Mallarmé, Valéry or Nietzsche. On the other hand, the philosopher-artist teaches us to return to the origins to find strong ties in the movements of dance, movements capable of welcoming the categories of life.

This way of writing, traced by the mentioned poets-philosophers or philosophersartists, associated with a non-systematic thought, a thought that accounts for ambiguity, contradiction, dialectic or fragility, as it has been mentioned, is relevant in approach to expressive forms such as dance. At the same time, the introduction of the notion of the potential body, no longer discreet and separate, opens new expressive horizons and transgresses the categories and the institution of art, surpassing the mere social function. It is precisely what Valéry does, which disconnects the dance from its social version and shows its ontological status; That is, dance as a gesture disconnected from acting. How, then, to understand these new gestures?

\section{Performativity AND DeVice: ReVisiting THE Body-IN-MOVEMENT}

If with modernity the paradigm would be placed at the level of an autonomy, with postmodernity the ontological status of dance is discussed from a heteronomy: a place

\footnotetext{
${ }^{5}$ This plastic possibility, together with the abandonment of rigid forms, as the academic dance proposed, with which Isadora Duncan definitively breaks, generates the necessary rupture for the dance to be re-found as an autonomous genre and to claim the author status.

${ }^{6}$ Argentina (Antónia Mercé, 1890-1936) was born in Buenos Aires, but soon went to Spain. The combination of Spanish folklore with academic dance, coupled with her dramatic instinct, proved surprising in the making of an artistic product.

${ }^{7}$ Assuming himself to be a disciple of Mallarmé, Valery would have hesitated, as he himself confesses, to write his work on dance, since, according to him, Mallarmé would have said everything on the subject. However, although in both dance the pure state is a starting point for further reflections, Valéry tries a different approach.
} 
where the multiplicity of stories will be found. As Michel Maffesoli tells us about this paradigmatic change: "it is no longer autonomy - I am my own law - that prevails, but heteronomy: my law is the other" (Maffesoli, 2011, p. 23). Thus, the question how to understand the new gestures presupposes, right away, an identity as fragile one. As postmodernity shows us, rather than in the individual, we must think of the person (persona) and, in Maffesoli's words, the person who plays several roles in the tribes to which he adheres implying a multiplication of identities. Says Maffesoli:

each only exists in and through the gaze of the other. And this other may be that of the tribe by affinity, that of the otherness of nature, or even the great Other that is the deity. Mergers, confusions of various orders that remind us of the Dionysian myth.(2011, p. 23)

In this change from autonomy to heteronomy, to a questioning of emerging gestures that, in addition to breaking with more or less established categories, assume mixed and contaminated values, there will be a need to confront at least two types of approaches.

Firstly, there is a need to validate the gestures through an open identification process: distinct, but not imprisoned in a classification. There are several examples of attempts to identify gestures that, irrespective of how stereotyped they may be, are relevant for a deepening of the ontological status of dance. Doris Humphrey (1959) distinguished the types of movement by social, functional, ritual and emotional gestures, the latter being the subject of dancing itself. In a different approach and a more communicational logic, Alessandro Pontremoli (1997) would designate the "coreutic gesture" as the one that best applies to dance. The author begins by distinguishing the mimic gesture (iconic mimesis, naturalistic gesture) from the pantomime (strongly codified and conventional, stylized gesture) to reach the coreutic gesture. Pontremoli says: "between these two extremes seems to be, finally, the apparently free, assemantic, unconventional and open coreutic gesture" (1997, p. 29). However, this openness does not call into question the idea of communication. On this, the author states:

only apparently a doing resends itself directly, in fact finds its most correct placement in a horizon of discourse constituting itself as a saying, as a writing, even in the case of manifestations that programmatically do not intend to mediate some content, such as the choreographies of Merce Cunningham or those of Lucinda Childs. (Pontremoli, 1997, p. 23)

The whole communication apparatus is there and happens independently of the intentionality of the content to be transmitted by the dance. The strategies of choreographic composition - as abstraction, non-figuration, composition without logical narrative, at bottom, anti-representationalist attempt - do not resist the imaginal appeal (world crossed by image, imaginary, symbolic and immaterial) (Maffesoli, 2011, p. 24) that the moving body summons, where it is always possible to narrate the moving body. Pontremoli tells us: "the support of a gesture is never abstract, it is the story of a soul, a polysemous revelation of an intentional center, upon which all eyes converge and from which all eyes move" (1997, p. 35). 
This leads us to the second point of approach to the emergence of new, plural gestures. By breaking with a logic of opposition between means and ends, as we have seen, gestures must be thought of in their condition of mediality. The gesture is understood as support, as Pontremoli tells us, or as the mediality of "communicating a communicability", as Giorgio Agamben will say in his reflections on the gesture and on dance as a gesture. Agamben specifies that:

if dance is a gesture, it is (...) because it consists entirely of bearing and of displaying the medial character of bodily movements. The gesture consists in displaying a mediality, in making visible a medium as such. In this way, the being-in-the-medium of man becomes visible, and the ethical dimension is opened to him. (1997, p. 20)

Mediality - as the one displayed - moves us into an ethical opening because man becomes visible and a given alienating movement is interrupted. If we go back, it is no coincidence that the epic theater of Bertolt Brecht is constructed by citation as a political and ethical act, where the citation is, above all, interruption, the taking of position against an alienated state. As Walter Benjamin notes, in relation to Brecht's epic theater, interruption is a fundamental procedure in the structuring of form because it is a process where, rather than the development of actions, it is a matter of representing situations. "Citing a text implies interrupting the context in which it reenters" (Benjamin 1998, 131). And, according to Benjamim: "the actor must have the ability to space his gestures, like a typographer's words. This effect can be obtained when the actor quotes his own gesture on the scene" (1998, p. 131).

As a procedure, the interruption, in addition to the reduction of gestures, generates intervals that tend to limit the illusion of the public, helping it to take critical positions. Lastly, the importance of not diminishing the argumentative power in favor of the suggestive in the modes of production. Something that, strategically, in the Brechtian view, can be achieved when opposed to organic growth and montage as a difference of treatment between the dramatic form of theater and the epic form of theater, between "man as a fixed data" and "man as a process". The meta-discursive effect plays a fundamental role in the way the images are generated and interpreted, and at the same time, in the way in which an ethics of form is drawn: spacing, visibility of an unfolding, expansion. Thus, the device apparatus of the work (strategies and principles of construction) is tested in the confrontation with the medial character of the gesture and the openness to which the work is exposed.

It is the mediality of the work that allows the multiplication of subjects and processes of subjectivation in the confrontation between living bodies and devices (Agamben, 2009). It is in this communicating confrontation that one must think of a responsible relationship between the traditional emitters and receivers, a relation without hierarchies where both elaborate and authorize all the discourse aroused by a given event; and where, rather than being towards the event, they are an event. It is, in principle, this disassembly of the device that can make it more privileged access to a work of art and less 
control machine of knowledge and power. The work becomes the pretext for an alternative discourse and sometimes detached from a rigid process of identification. The work, more than an object of beauty, functions as a device that promotes an aesthetic experience without a fixed, yet elastic, open field, where the work is captured to be reworked, to be performed (not just informed) ${ }^{8}$. The closure of this situation is perhaps in the sense that the sensation provoked by the work starts from the configured field of the experience that the device allows to create, but since this field is absent from rules, it becomes itself moldable and changeable by the possibility to take free position during our fruition process. There is a limit imposed by the device, but in a way to reduce possibilities and not to define the pattern to generate. (This explains the importance of the responsibility factor in the construction of the device). What is presented phenomenologically is materialized by a positioning determined both by the performer and by the viewer, evidencing the ethical dimension (taking position and mode of action on this experience).

The enlarged Foucault's notion of device is retaked by Agamben and according to him, the device can be anything capable of capturing, guiding, determining, intercepting, modeling, controlling and ensuring the gestures, behaviors, opinions and discourses of living beings (Agamben, 2009). Devices are incessantly captured by living beings and may be of a different nature, even language itself, according to the author, may be considered one of the oldest devices (Agamben, 2009, p. 41). In this enlargement we can understand the work of art as a device in the sense of providing a field of ethical re-elaboration of the relationship, now dynamic, multiple and unpredictable, between sender and receiver. The economic domain of this relationship consists of the domain of the terms in which the work is presented or is recognized. It will be by this way that emerging gestures launched by the dance in the postmodern era, strategically, defunctionalize the established categories (be it the ballet or the modern dance). At the same time that gestures of the world are brought to the surface, in the context of dance, gestures of everyday life - familiar gestures where new powers of intervention and the role of dance can be found in the general panorama of the arts - strangeness is generated in the category where these gestures could be placed generating, thus, to the infinite, the doubt whether or not it is dance.

It is, therefore, within the framework of this problematization, not so much between emitters and receivers, but between living bodies and devices, that, at the same time ethical questions are posed (the work loses its founding authorship to be a ready vehicle for transformation), it may be identified epistemological questions as well in the sense of access to a given knowledge (identification of relations of power and knowledge involved in the construction strategy of the work). Regarding this possibility, in a reflection on ethics and communication theories, the authors Martino e Marques (2014) release the possibility of an intersection between ethics and epistemology where the emitter and receiver do not connect through a symmetrical or asymmetrical relationship, but through a rhizomatic structure of interaction. As the authors say:

\footnotetext{
${ }^{8}$ See Martins, 2016.
} 
one of the points of intersection between the ethical and the epistemological reveals itself in the fact that the explanation of 'what happens' can also be seen as a proposition on "what to do from it". They reveal in the examination of Communication Theories conceptions of an ethos and dissensual forms of expression and interaction that invent ways of being, seeing and saying, configuring new subjects and new modes and scenes of collective enunciation, in what Esteves (2007) calls agonistic of collective life. (Martino \& Marques, 2014, p. 140)

Irrespective of whether we can pose important questions to the perspective of the intersection between ethics and epistemology, this possibility reinforces the idea of a responsible, meta-discursive and detached movement in the connection between the agents involved in a communicative flow.

The understanding of the choreutic gesture as a saying, as discourse, is the best approach we can make to dance. Away, therefore, will be all the insistence on codifying it, either in practice or in theory. And the whole course of contemporary dance should lead the dance to its own estrangement by the elasticity with which it broadens and projects in its creative spiral. When we situate ourselves in the opening of the gesture as pure mediality communicated to men, we have separated it from any attempt to fix it to a meaning, a specific reference - the ethical dimension and a new life of the work while transformation marked by a positioning. At the same time, mediality sets as the necessary opening to an ontological discussion of the body-in-motion that will overcome, as we have already said, the discussion around its correspondences. In this sense, it is generally a discussion that is closer to what is procedural than what happens as an institution or as a product.

In this expanded picture of the performative gesture, it is at the disciplinary juncture that we can best observe specific conceptions of the subject and of his political relations, and also, meta-reflexively, of the field of operations itself. It is what allows us the understanding of the work from the notion of device. The network, the type of network established among the various actors of the work, defines the critical field from which the work is reborn. This becoming of the work functions by the depolarization of the gesture in relation to the surrounding and to the material objects (that is, the living body not as exclusive center). The dance or performative body can thus expand: at the level of a relation between material objects without an organic body; at the virtual level for prostheses that can be established. The gesture becomes real or virtual, visible or invisible. This is what happens in works by authors like William Forsythe (choreography exclusively performed by objects or projects of dance with the new technologies) or, in another stance, the Brazilian artist, Lygia Pape with its Neo-concrete Balés (hidden body that works literally as a motor).

In conclusion, we could reinforce here the idea that, in dance, the passage of an ontological dimension of the gesture to an ethic of form does not mean a reduction or a substitution. The displacement from an ontological discussion to an ethical discussion of dance is only a circulation between body-in-movement and gesture and it is in this circulation that the dancing body is becoming. The two axes of discussion have in common 
the notion of mediality as a fundamental presupposition. The importance of thinking the mediality not only as a support, but as a movement of inclusion and devolution requires: 1) to keep open any discursive plan and to include the Other; 2) disregard the tendencies of imprisonment of the work in categories; 3) to measure knowledge by identifying the construction strategies or the meta-discourses involved.

Thinking about the work through the notion of device allows us to understand dramaturgical strategies of distances, such as epic and citability, and thus to return a thinking gesture (a thought and thoughtful gesture), which can be discussed in an ethical perspective without direct dependence of an ontology. The mediality as product, the displayed, the said, carries in itself, as it was said, the ethical opening. Discuss the gesture within the limits of its visibility. Mediality, therefore, is the challenge to a performance that is intended to be resistant to a categorization and that dialogues through postmetaphysical thinking. The subjectivation process generates active (political) subjects. On the other hand, the ontological discussion allows us to recover a dancing gesture as a gesture harvested, in a perpetual revisitation and reinvention; a gesture in continuous movement that occurs within the limits of the visibility of its transmutation into a choreutic gesture. In this game of approach and abandonment of the referent, the work becomes unstable and impermanent, constantly becoming. This is its ontological status: procedural and discursive value that calls us and attracts us to look and read the work as an expanded form, as a body-in-movement and to go through the processual movement as a choreutic gesture: a gesture that interrupts, suspends, locates and provokes strangeness and disconfort. This gesture, in turn, is doubly assumed as proper to the thought and proper of dance. In this case, we are facing a field of reproduction of the multiple-subject.

\section{Traduzido por Né Barros}

\section{BibLIOGRAPHIC REFERENCES}

Agamben, G. (1997). Notas sobre o Gesto. In M. T. Cruz (Ed.), inter@ctividades (pp. 16-21). Lisboa: C.E.C.L.

Agamben, G. (2009). O que é o contemporâneo e outros ensaios. Chapecó: Editora Argos.

Barros, N. (2009). Da materialidade na dança. Porto: C.E.A.A./ESAP.

Benjamin, W. (1955). L'Opera d'arte nell'epoca della sua riproducibilità técnica. Torino: Einaudi.

Goldberg, R. (1988). Performance Art. London: Thames and Hudson.

Humphrey, D. (1959). The Art of making dances. New York: Grove Press.

Maffesoli, M. (2011). Pós-modernidade. Comunicação e Sociedade, 18, 21-25.

Mallarmé, S. (1886/1976). Ballets. Igitur -Divagations - Un Coup de Dés. Paris: Éditions Gallimard.

Mallarmé, S. (1893/1976). Autre étude de danse. Les fonds dans de le Ballet. D'après une indication récente. Igitur -Divagations - Un Coup de Dés. Paris: Éditions Gallimard. 
Martino, L. M. S. \& Marques, A. C. S. (2014). Ética e Teorias da Comunicação: poder, interações e cultura participativa". Comunicação e Sociedade, 25, 138-153.

Martins, F. (2016). Sentido Narrativo - Da formatividade à performatividade. Porto: Afrontamento.

Pontremoli, A. (Ed.) (1997). Drammaturgia della danza. Milan: Euresis Edizioni.

Sorell W. (1981), Storia della danza. Bologna: II Mulino.

Valéry, P. (1957). Philosophie de la danse. In Oeuvres I, Variété - Théorie poétique et esthétique. Paris: Gallimard.

Valéry, P. (1960). “L'Âme et la Danse”. In Oeuvres II. Paris: Gallimard.

\section{BiOgRAPHICAL NOTE}

Né Barros, choreographer and researcher at the Institute of Philosophy, Research group of Aesthetics, Politics \& Knowledge (U.P.). PhD from the FMH (U.L.), Master in Dance, Laban Center City University, London. Artistically, she began her training in classical dance and later works contemporary dance and choreographic composition in the United States, Smith College. Choreographed for Balleteatro, National Ballet Company, Gulbenkian Ballet and Aura Dance Company. In her choreographic projects she has collaborated with several artists of the arts, cinema, theater and music. Assistant Professor at ESAP. Has several articles published. She is author of the book $\mathrm{Da}$ materialidade na dança (On the materiality of dance) and editor of Artes Performativas: Novos Discursos (Performing Arts: New Discourses), Das Imagens Familiares (On Familiar Images), Dança: o corpo e a casa (Dance: the body and the house), Story Case print and Deslocações da Intimidade (Displacements of the Intimacy). Founder and co-director of the International Film Festival Family Film Project (Memory, Archive and Ethnography) and Balleteatro (Performing art Centre).

E-mail: nebarros@gmail.com

Rua do Ouro, 108, apt 5.5 4150-552 Porto, Portugal

* Submitted: 30-09-2016

* Accepted: 22-01-2017 